\title{
Community Structure along Timberline Ecotone in Relation to Micro-topography and Disturbances in Western Himalaya
}

\author{
Ishwari D. RAI ${ }^{1}$, Bhupendra S. ADHIKARI ${ }^{1 *}$, Gopal S. RAWAT ${ }^{1,2}$, Kiran BARGALI ${ }^{3}$ \\ ${ }^{1}$ Wildlife Institute of India, PO Box 18, Chandrabani, 248001 Dehradun, Uttarakhand, India; adhikaribs@wii.gov.in (*corresponding author) \\ ${ }^{2}$ Ecosystem Services, International Centre for Integrated Mountain Development, GPO Box 3226, Kathmandu, Nepal \\ ${ }^{3}$ Kumaun University, Department of Botany, DSB Campus, 263001 Nainital, Uttarakhand, India
}

\begin{abstract}
Four communities, formed as a result of locally varying site conditions, were identified and studied along the timberline ecotone in part of Kedarnath Wildlife Sanctuary (KWS). Communities on the vicinity of pilgrimage site and along gentler slopes were highly disturbed having sharp timberlines, while those located far and in the steep slopes were less affected, forming a little broader transition. The tree density ranged from 340 to 780 trees/ha, while the basal cover of communities varied greatly and ranged from 6.4 to 55.1 $\mathrm{m}^{2} /$ ha. Birch dominated community had lowest basal area among all the communities, while mixed community had the highest. In all the respective communities, from subalpine zone, density and basal area was higher than that of timberline zone. The Importance Value Index (IVI), which used to determine the overall importance of each species in the community structure, of dominant species at timberline was more than 200 in all the communities, except in the mixed community. Influence of the anthropogenic disturbances was apparent on the regeneration performance of all the studied tree species. Rhododendron campanulatum was the dominant shrub species of the area and formed krummholz, while distribution of other species varies greatly with forest type. The shrub density decreased from high to low disturbance, while the herbaceous species density increased with prevalence of a few species favoring the high disturbance (grazing). The shrub and herb species richness was higher in the ecotone zone. Some uncommon species like Balanophora involucrata and Aralia cissifolia were also found at timberline. Three species of Lady's Slipper orchid were reported together from Betula utilis community at timberline ecotone.
\end{abstract}

Keywords: birch, disturbance, Kedarnath Wildlife Sanctuary, regeneration, transition zone, vegetation composition

\section{Introduction}

Timberline is the most striking, climatically governed and ecologically important vegetation boundary, which is marked by a change in site conditions and plant communities when crossing the forest limit (Holtmeier, 2003). Timberline not only delineates area of abrupt change in tree morphology (Tranquillini, 1979), but also depicts the effects of abrupt change in climatic conditions. Woody plant species, which subsequently determine many of the ecological conditions, found within forest represented a key biological group for these forest ecosystems (Stapanian et al., 1997). At timberline zone structure of plant communities is largely influenced by the frequently occurring disturbances, naturally or due to anthropogenic activities. Apart from disturbances, topography, climate, altitude, aspect and herbivory play a significant role to determine structure of forest communities. All these factors along with forest succession are responsible for spatial heterogeneity of forest structure (Timilsina et al., 2007). The factors acting on plant diversity at fine scale were not the same with those acting at larger spatial scale (Whittaker et al., 2001; Weiher and Howe, 2003). Therefore, under- standing towards the dynamics of these forest ecosystems and coupling to other components of the biosphere proved to be important (Shugart et al., 2010).

Any transition zone between the two ecosystems was known to be very sensitive to the biotic and climatic factors, because species are adapted for the microclimatic conditions. These processes were complex and timberline ecotones were not linear climate change indicators, as the response might be a succession of lagged and rapid changes (Alftine and Malanson, 2004; Camarero and Gutiérrez, 2007; MacDonald et al., 1998). Large portion of the past and current literature was dealing with the global distribution of high-altitude forests, with the question of what environmental factors limit tree occurrence at upper limit around the world (Körner and Paulsen, 2004; Tranquillini, 1979; Wardle, 1974). At present, the common thinking is that altitudinal timberlines are currently advancing to higher altitudes such as latitudinal timberlines, which are moving further north in northern hemisphere (Parmesan, 2006; Shugart et al., 2001; Weiser and Tuasz, 2007), while this trend have many anomalies, due to its dependency upon local and regional conditions (terrain type, orographic influences, herbivory, disease) and anthropogenic 
42

influences (Cairns and Moen, 2004; Weiser and Tuasz, 2007). In the current scenario it is interesting to find out the rate at which the timberline may advance in response to global warming (Grace et al., 2002). In case of Western Himalaya it is very difficult to track changes along the timberline, where prevalence of high anthropogenic pressure still remaining for centuries. It is very important to monitor these sensitive areas for future changes due to climate or land use practices, where there is a complete lack of baseline information. The present study deals with small scale heterogeneity in community structure and composition of different forest types along the timberline and their comparison with the respective forests at subalpine zone.

\section{Materials and methods}

\section{Study area}

The study area is located in Tungnath area $\left(30^{\circ} 29^{\prime}\right.$ $30^{\circ} 30^{\prime} \mathrm{N}$ Lat and $79^{\circ} 12^{\prime}-79^{\circ} 13^{\prime} \mathrm{E}$ Long) of Kedarnath Wildlife Sanctuary (hereafter referred as KWS) between ana is the common grass species, while Carex spp. and Kobresia royleana represent the major sedges in the region.

\section{Geology, soil and climate}

The rocks around Tungnath are mainly mylonitized gneisses, augen gneisses, schists and granites constituting Munsiari Formation (Agrawala, 1973). The weathering bedrocks, that provide the bulk of the loose material in these mountains, are crystalline and metamorphic, with sedimentary deposits of Paleozoic age (Gansser, 1964; Gupta, 1964). The soil texture is sandy loam and acidic in nature with a $\mathrm{pH}$ ranged between 4 and 5 .

The annual climate of the region can be divided into 3 prominent seasons; long winter (October to April), short summer (May to June) and rainy season (July to September). Mean Annual temperature at the timberline ecotone $(3300 \mathrm{~m})$ ranged between-8.91 (January) and $25.6^{\circ} \mathrm{C}$ (May) with an average of $6.65 \pm 0.68^{\circ} \mathrm{C}$. Mean temperature of the warmest month was $12.56 \pm 1.23^{\circ} \mathrm{C}$, in July (Fig. 2). Annual precipitation was $2410.5 \pm 432.2 \mathrm{~mm}$, of

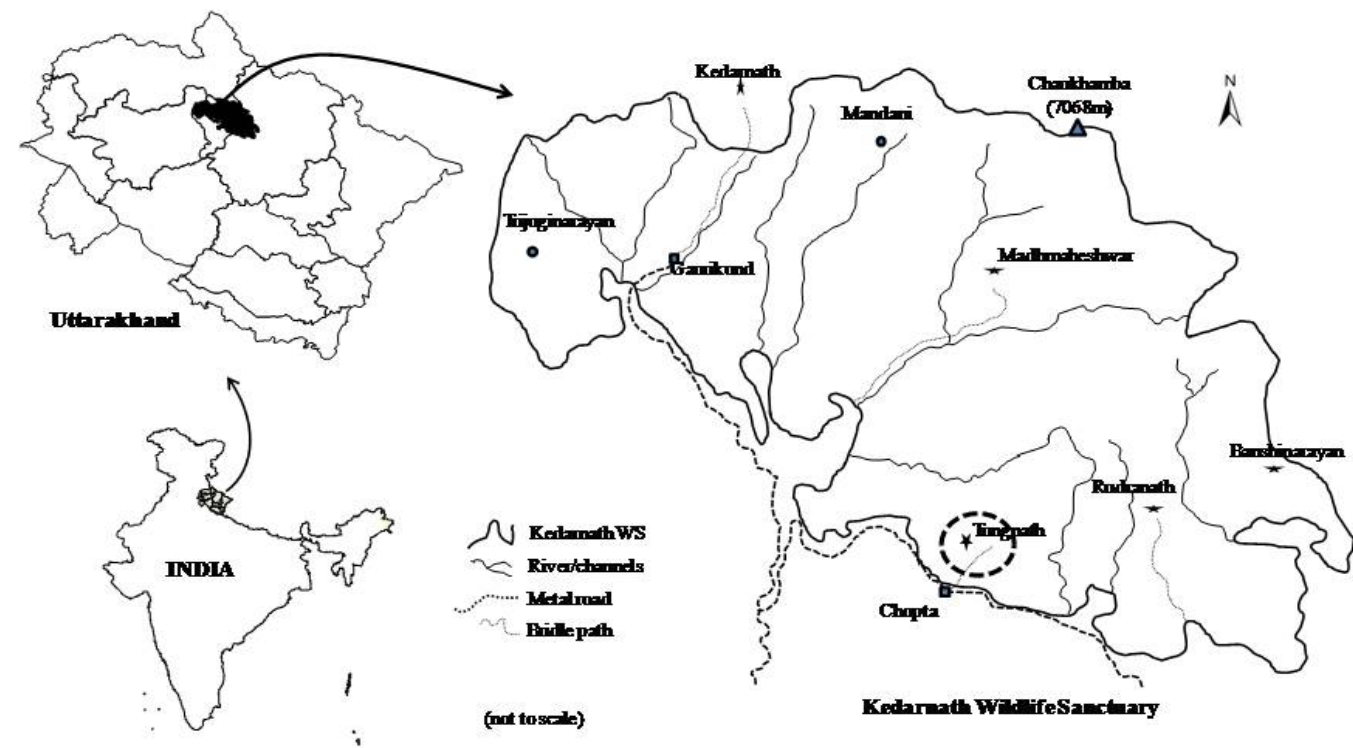

Fig. 1. Map of the study area. Location of Kedarnath WS inside the map of Uttarakhand and Tungnath inside the map of KWS (Kedarnath Wildlife Sanctuary)

3100-3400 $\mathrm{m}$ asl (above sea level) in Uttarakhand, Western Himalaya (Fig. 1). The area forms the upper catchment of the river Alaknanda, a major tributary of Ganga river. The forest of the study area falls under the subalpine one, which gives way to vast alpine meadows beyond the timberline ecotone. Preponderance of shade loving species (Betula utilis and Abies spectabilis), on north facing slopes and light demanding species (Q. semecarpifolia and $R$. arboreum) on south facing slopes with low tree species richness, is the characteristic feature of the subalpine forests along a few other associated species, viz., Acer caesium, Prunus cornuta, Taxus wallichiana and Sorbus foliolosa. The krummholz formation by Rhododendron campanulatum dominates the shrub layer and Danthonia cachemyri-

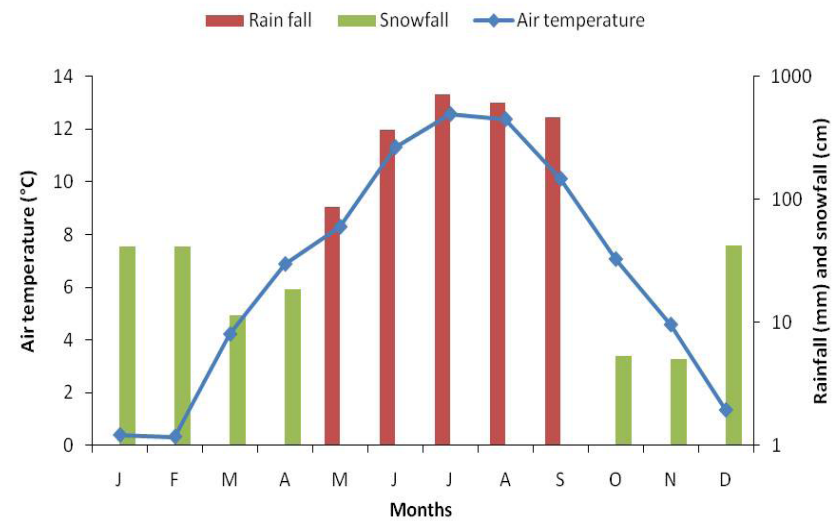

Fig. 2. Mean air temperature, rainfall and snowfall at timberline ecotone in the study area (period 2008-2010) 
which $89.5 \%$, recorded during June-September and snow cover lasts for $85 \pm 22.7$ days/year (Adhikari et al., 2011).

\section{Vegetation sampling}

Four major communities, viz., Betula utilis (birch, Photo 1), Abies spectabilis (silver fir, Photo 2), Quercus semecarpifolia (kharsu oak, Photo 3) and Abies-Quercus (mixed, Photo 4) were identified on physiognomic basis and composition with various levels of disturbance regime at timberline ecotone. Two representative hectare plots (200 m $\times 50 \mathrm{~m}$ each) were identified, one at timberline ecotone and the other in subalpine zone (altitudinal $100 \mathrm{~m}$ down to timberline ecotone) for each community to find out the difference in species composition and regeneration status. Ten, $10 \times 10 \mathrm{~m}$ quadrats were laid within each hectare plot for trees $(>20 \mathrm{~cm}$ circumference at breast height, $\mathrm{cbh})$ and saplings ( $<20 \mathrm{~cm} \mathrm{cbh})$ and every individual tree and sapling were measured for girth at $1.37 \mathrm{~m}$. Within each 10x10 m quadrat, a smaller quadrat $(5 \times 5 \mathrm{~m})$, for shrubs, was laid. Twenty five quadrats $(1 \times 1 \mathrm{~m})$ were laid randomly for herbaceous vegetation within the hectare plot. The canopy cover of trees, tree height and canopy depth and canopy width of trees were measured with the help of densitometer, clinometer and measuring tape, respectively. Level of disturbance was assessed qualitatively on the basis of intensity and duration of grazing, livestock, number of sheep and goat, distance from the herder's camp, logging, lopping and fuelwood collection.

Three vegetation layers, i.e. tree, shrub and herb were analysed for species richness, density, diversity and regeneration of tree species following Curtis and McIntosh (1950) and Phillips (1959). Total basal area of tree species was used to determine the relative dominance of a species. Importance value index (IVI) was calculated by sum of relative frequency, relative density and relative dominance following Phillips (1959). The Shannon-Weiner diversity Index (Shannon and Wiever, 1963) and Sorensen's similarity Index (Sorenson, 1948) was computed following Magurran (1988), while evenness (equability) was calculated after Pielou (1966). Species richness was determined as the number of species per unit area (Whittaker, 1975).

\section{Results}

Variance in disturbance level among communities

High altitude ecosystems are extremely sensitive to anthropogenic and climatic disturbance (extreme events). At the timberline zone tree species struggle for survival, growth and regeneration due to harsh climatic conditions. Disturbance in the form of grazing, especially by cattle (buffalo and cow), horse and mule, has negative effect on tree regeneration and growth of under canopy species. In silver fir community disturbance falls at its maximum level. Maximum herder's camps and seasonal shops, situated nearby, were largely made by fresh logs, in which the consumption of fuel wood was very high. This community

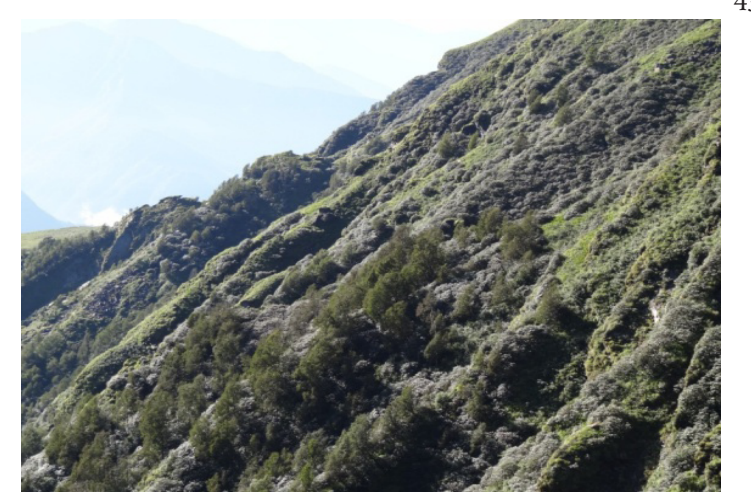

Photo 1. Betula utilis community at Timberline

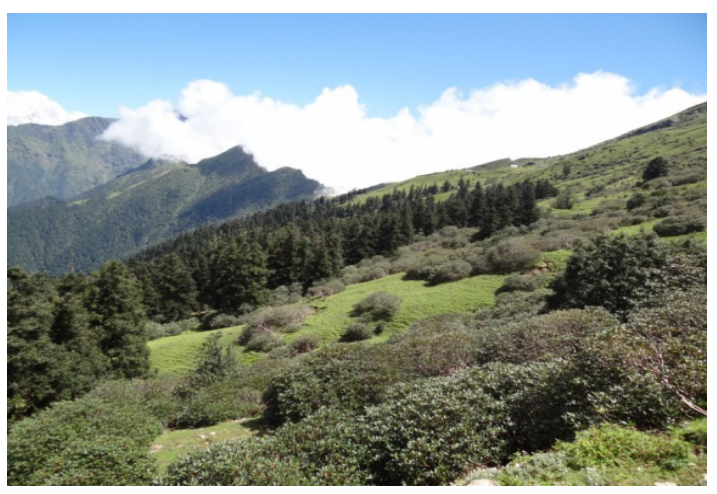

Photo 2. Abies spectabilis community at Timberline

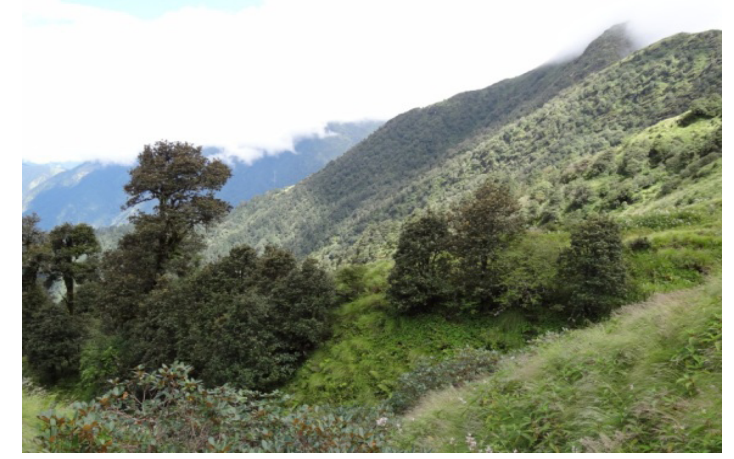

Photo 3. Quercus semecarpifolia community at Timberline

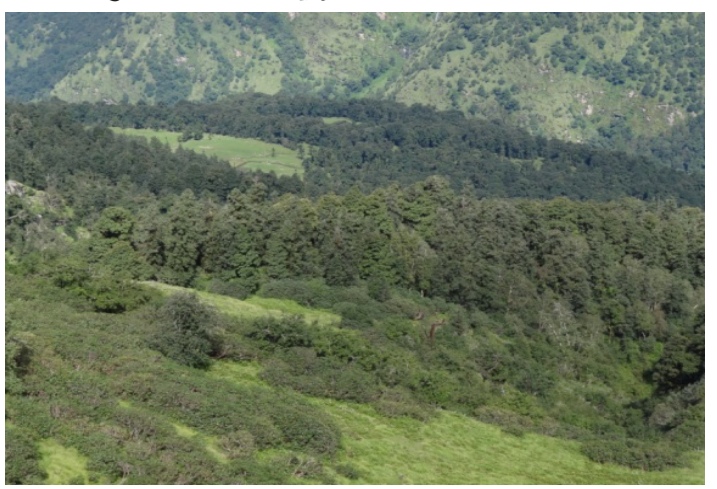

Photo 4. Mixed community at Timberline

was heavily grazed by sheep, goats and cattle in the entire growing season. Fuelwood consumption, logging and soil erosion was frequent in this community. Kharsu oak community was less affected as compared to the silver fir community, where unproductive domestic cattle were left by 
44

villagers for several months, but camps were away and less fuel wood consumption was noticed. Due to natural barrier (deep gorge) and remoteness, mixed and birch communities were less affected, while occasional grazing by sheep, goats and fuelwood collection was observed in later community. The growth of herbs starts off late due to shady aspect and ends early; hence grazing duration was less. The subalpine zone of the respective timberline communities were less affected, except the silver fir community.

\section{Species richness and diversity}

Along the timberline ecotone species richness was highest in birch community followed by kharsu oak and mixed communities. Tree species richness was highest in mixed community and lowest in birch community. In low disturbed birch community, tree species richness was lowest among all communities, but shrub and herb species richness was highest. The species richness of shrub and herb was recorded lowest in the highly disturbed community formed by silver fir. The tree species richness ranged from 3-5 and there was not much variance in terms of species richness, while distribution of species highly depends on the site specific microclimate and reflects through evenness and diversity values.

In the subalpine zone, overall species richness was lower than that of timberline ecotone for any community, while tree species were more in number. Shrub and herb species richness was equal or lower than that of timberline ecotone, except in the highly disturbed silver fir community (Tab. 1). Tree, shrub and herb species evenness and Shannon-Wiener index values were minimum in less disturbed communities and maximum in highly disturbed forests (Tab. 1).

Tab. 1. Species richness, Shannon's diversity index and evenness in different forest communities

\begin{tabular}{|c|c|c|c|c|c|c|c|c|c|}
\hline \multirow[t]{2}{*}{ Parameters } & \multirow[t]{2}{*}{ Taxa } & \multicolumn{2}{|c|}{ Birch } & \multicolumn{2}{|c|}{ Silver fir } & \multicolumn{2}{|c|}{$\begin{array}{c}\text { Kharsu } \\
\text { oak }\end{array}$} & \multicolumn{2}{|c|}{ Mixed } \\
\hline & & $\mathrm{TL}$ & SF & $\mathrm{TL}$ & SF & $\mathrm{TL}$ & SF & $\mathrm{TL}$ & SF \\
\hline \multirow{3}{*}{$\begin{array}{l}\text { Species } \\
\text { richness }\end{array}$} & Tree & 3 & 4 & 4 & 4 & 4 & 5 & 5 & 7 \\
\hline & Shrub & 12 & 11 & 5 & 8 & 9 & 10 & 9 & 9 \\
\hline & Herb & 60 & 47 & 44 & 53 & 59 & 34 & 54 & 42 \\
\hline Total & & 75 & 62 & 53 & 63 & 72 & 49 & 68 & 58 \\
\hline \multirow{3}{*}{ Diversity } & Tree & 0.47 & 0.86 & 0.76 & 0.28 & 0.68 & 0.99 & 1.42 & 1.52 \\
\hline & Shrub & 1.57 & 1.46 & 0.85 & 1.61 & 1.54 & 1.93 & 1.69 & 1.69 \\
\hline & Herb & 3.23 & 2.65 & 2.52 & 3.17 & 3.25 & 2.85 & 3.06 & 2.78 \\
\hline \multirow[t]{3}{*}{ Evenness } & Tree & 0.43 & 0.62 & 0.55 & 0.20 & 0.49 & 0.61 & 0.88 & 0.78 \\
\hline & Shrub & 0.63 & 0.61 & 0.53 & 0.77 & 0.70 & 0.84 & 0.77 & 0.77 \\
\hline & Herb & 0.78 & 0.69 & 0.67 & 0.79 & 0.79 & 0.81 & 0.77 & 0.74 \\
\hline
\end{tabular}

\section{Similarity among communities}

More than $50 \%$ similarity was observed in terms of tree species composition among the communities at timberline. Similarity between kharsu oak and mixed tim- berlines was the highest (89\%), whereas timberline communities, formed by silver fir and kharsu oak, were least similar (50\%). Similarity of tree species had broader range (25-83\%) along the subalpine forest than in timberline zone due to high species richness. Similarity was found the highest between kharsu oak and mixed communities (100\%), whereas similarity of birch forest with all other forests was comparatively low (25-54.5\%). Composition of shrub layer in the silver fir community was different from all other communities and similarity with other communities was between $47-61 \%$, because only a few species survived and dominated.

Along the subalpine zone mixed community had maximum similarity (54.5-83\%) with other communities, whereas birch and silver fir community had minimum similarity in terms of species composition (25\%). The similarity among shrub species was higher $(>80 \%)$ in most of the communities. Herbaceous species composition was more or less similar among the communities and only a few species were restricted to a particular community and the difference was in the dominant species' density.

\section{Community structure}

\section{Tree layer}

Micro-habitat specific dominance of tree species was evident in the timberline zone. The result revealed that dominant species had IVI value $>200$, except in mixed timberline community, formed by silver fir and kharsu oak, while in the subalpine zone IVI was low for dominant species. $R$. arboreum and $S$. foliolosa were present in all communities, while T. wallichiana only in kharsu oak community. Trees were sparsely distributed along the timberline ecotone with low density; hence total basal area (TBA) was also low as compared to subalpine forest. Abrupt termination of forest due to high anthropogenic pressure, in silver fir community at timberline, lead to the stand structure with large number of trees in higher girth classes and natural regeneration was absent, hence highest TBA among all communities. Along the timberline ecotone the highest TBA was recorded in the silver fir community $\left(55.1 \mathrm{~m}^{2} \mathrm{ha}^{-1}\right)$ followed by mixed $\left(42.0 \mathrm{~m}^{2} \mathrm{ha}^{-1}\right)$, kharsu oak $\left(30.0 \mathrm{~m}^{2} \mathrm{ha}^{-1}\right)$ and birch $\left(6.4 \mathrm{~m}^{2} \mathrm{ha}^{-1}\right)$ communities, where tree density was $580,420,340$ and 780 trees/ ha, respectively. In the subalpine zone of these communities, TBA was ranged between $28.5 \mathrm{~m}^{2} /$ ha (birch) to 65.2 $\mathrm{m}^{2}$ / ha (kharsu oak), while density ranged between 420 trees/ha (birch) and 810 trees/ha (kharsu oak) in these communities (Tab. 2). Due to uneven terrain most of the species had either random distribution and some species had contiguous distribution along the communities. Except birch community, tree density was low along the timberline ecotone as compared to subalpine zone, for silver fir and kharsu oak community, and more or less the same in mixed community. 
Tab. 2. Comparative account of density (trees/ha), TBA $\left(\mathrm{m}^{2} / \mathrm{ha}\right)$ and IVI of tree species in different communities along timberline and subalpine forest

\begin{tabular}{|c|c|c|c|c|c|c|c|c|c|}
\hline \multirow{3}{*}{ Tree species } & \multirow{3}{*}{ Parameters } & \multicolumn{8}{|c|}{ Communities } \\
\hline & & \multicolumn{2}{|c|}{ Birch } & \multicolumn{2}{|c|}{ Silver fir } & \multicolumn{2}{|c|}{ Kharsu oak } & \multicolumn{2}{|c|}{ Mixed } \\
\hline & & $\mathrm{TL}$ & SF & $\mathrm{TL}$ & SF & $\mathrm{TL}$ & SF & $\mathrm{TL}$ & SF \\
\hline \multirow{3}{*}{ Betula utilis } & Density & 540 & 310 & - & - & 10 & - & 110 & 70 \\
\hline & TBA & 5.7 & 15.4 & - & - & 0.1 & - & 5.5 & 4.7 \\
\hline & IVI & 261.8 & 175.4 & - & - & 10.6 & - & 46.9 & 25.7 \\
\hline \multirow{3}{*}{ Abies spectabilis } & Density & - & - & 300 & 490 & 10 & 50 & 230 & 250 \\
\hline & TBA & - & - & 43.5 & 59.3 & 2.7 & 6.1 & 20.8 & 20.9 \\
\hline & IVI & - & - & 208.6 & 268.1 & 19.0 & 29.9 & 110.6 & 96.0 \\
\hline \multirow{3}{*}{ Q. semecarpifolia } & Density & - & - & - & - & 280 & 430 & 170 & 230 \\
\hline & TBA & - & - & - & - & 26.9 & 46.5 & 11.6 & 24.0 \\
\hline & IVI & - & - & - & - & 243.4 & 167.2 & 67.2 & 89.5 \\
\hline \multirow{3}{*}{ Sorbus foliolosa } & Density & 20 & - & 100 & 10 & 40 & - & 250 & 110 \\
\hline & TBA & 0.1 & - & 6.8 & 0.4 & 0.3 & - & 2.4 & 1.7 \\
\hline & IVI & 12.2 & & 62.2 & 10.2 & 26.9 & & 64.8 & 29.0 \\
\hline \multirow{3}{*}{ R. arboreum } & Density & 20 & 30 & 10 & 10 & - & 310 & 20 & 80 \\
\hline & TBA & 0.5 & 3.5 & 0.04 & 0.4 & - & 11.9 & 1.8 & 9.1 \\
\hline & IVI & 26.0 & 43.1 & 11.4 & 10.2 & - & 89.8 & 10.5 & 40.1 \\
\hline \multirow{3}{*}{ Prunus cornuta } & Density & - & - & 10 & 10 & - & 10 & - & 10 \\
\hline & TBA & - & - & 4.8 & 1.1 & - & 0.2 & - & 1.1 \\
\hline & IVI & - & - & 17.7 & 11.5 & - & 6.3 & - & 6.2 \\
\hline \multirow{3}{*}{ Acer caesium } & Density & - & 40 & - & - & - & 10 & - & 30 \\
\hline & TBA & - & 1.4 & - & - & - & 0.5 & - & 0.4 \\
\hline & IVI & - & 24.1 & - & - & - & 6.8 & - & 13.5 \\
\hline \multirow{3}{*}{ Taxus wallichiana } & Density & - & 40 & - & - & - & - & - & - \\
\hline & TBA & - & 8.2 & - & - & - & - & - & - \\
\hline & IVI & - & 57.4 & - & - & - & - & - & - \\
\hline
\end{tabular}

Tab. 3. Shrub species density along Timberline ecotone and subalpine forest zones (individuals/ha)

\begin{tabular}{ccccccccc}
\hline \multirow{2}{*}{ Shrub species } & \multicolumn{2}{c}{ Birch } & \multicolumn{2}{c}{ Silver fir } & \multicolumn{2}{c}{ Kharsu oak } & \multicolumn{2}{c}{ Mixed } \\
\cline { 2 - 8 } & ${ }^{*}$ TL & ${ }^{*}$ SF & TL & SF & TL & SF & TL & SF \\
\hline Rubus niveus & 720 & 9080 & 240 & 3280 & 80 & 40 & 2360 & 5480 \\
Thamnocalamus spathiflorus & - & 10680 & - & - & - & 960 & - & 2920 \\
Spiraea bella & 8280 & 40 & - & 400 & 2240 & 800 & 160 & 1160 \\
Rosa sericea & 600 & 1240 & 40 & 1560 & 2480 & 1360 & 960 & 1040 \\
R. campanulatum & 400 & 360 & 2840 & 920 & 520 & 360 & 1760 & 840 \\
Salix denticulata & 5720 & 160 & - & - & 80 & - & 40 & - \\
Viburnum grandiflorum & 560 & 880 & 920 & 1320 & 360 & 200 & 640 & 440 \\
Cotoneaster acuminatus & 280 & 800 & - & 200 & 440 & 840 & 280 & 880 \\
Rhododendron lepidotum & 1880 & - & - & - & - & - & - & - \\
Lonicera myrtillus & - & 640 & 40 & 240 & - & 120 & 240 & 320 \\
Ribes glaciale & 40 & 1280 & - & 40 & 120 & - & - & - \\
Berberis jaeschkeana & 40 & - & - & - & 120 & 280 & 160 & - \\
Rosa macrophylla & 480 & - & - & - & - & - & - & - \\
Rhododendron barbatum & - & 40 & - & - & - & 80 & - \\
Spiraea canascens & 80 & - & - & - & - & - & - \\
\hline
\end{tabular}

${ }^{*}$ TL: Timberline and ${ }^{*}$ SF: subalpine forest 
46

\section{Shrub layer}

In most of the communities shrub density was lower along the timberline ecotone as compared to the subalpine zone. Lowest shrub density along timberline was recorded in silver fir community (4080 individuals/ha), where $R$. campanulatum was the only species and shrub density reached highest in birch community (19080 individuals/ha). Shrub density along the subalpine zone was the highest in birch community (25200 individuals/ha) and the lowest in kharsu oak community (5040 individuals/ ha). $R$. campanulatum was distributed most consistently along the timberline as well as in the subalpine zone. $R u$ bus niveus forms dense shrub layer in the shady and moist areas. A large number of regenerating individuals of hill bamboo (Thamnocalamus spathiflorus) were found in many localities, however, Spiraea canescens and Skimmia laureola were found restricted to some pockets only and a rare shrub species Aralia cissifolia was found only in birch dominated community (Tab. 3).

\section{Herb layer}

Herb density was recorded low along the timberline ecotone. In birch, silver fir, kharsu oak and mixed communities herb density was122.5, 238.6, 179.6 and 193 individuals $/ \mathrm{m}^{2}$, respectively along timberline ecotone. Along the subalpine forest herb density was 152.5, 245.8, 107 and 126.6 individuals $/ \mathrm{m}^{2}$ in birch, silver fir, kharsu oak and mixed communities, respectively. The highest herb density was found in silver fir community in both timberline and subalpine zones. Trachydium roylei and Oxygraphis polypetala were abundant mainly in grazed and open canopy areas along timberline. Birch community had the lowest herb density due to dense shrub layer and low disturbance

Tab. 4. The dominant herb species along the Timberline ecotone and subalpine forest in different communities. The density (individuals $/ \mathrm{m}^{2}$ ) values are in parenthesis

\begin{tabular}{|c|c|c|}
\hline $\begin{array}{c}\text { Commu- } \\
\text { nities }\end{array}$ & Timberline & Subalpine forest \\
\hline Birch & $\begin{array}{l}\text { Fragaria nubicola }(16.8) \\
\text { Viola biflora }(14.8) \\
\text { Smilacina purpurea }(11.1) \\
\text { Trachydium roylei }(8.5) \\
\text { Senecio alatus }(7.1)\end{array}$ & $\begin{array}{l}\text { Viola biflora (37.1) } \\
\text { Fragaria nubicola }(27) \\
\text { Polygonum amplexicaule (22.9) } \\
\text { Strobilanthes atropurpureus }(7.1) \\
\text { Impatiens sulcata }(6.6)\end{array}$ \\
\hline Silver fir & $\begin{array}{l}\text { Circaea alpina }(80.4) \\
\text { Fragaria nubicola }(28.8) \\
\text { Galium rotundifolium }(22.5) \\
\text { Polygonum amplexicaule }(15.5) \\
\text { Polygonum chinense }(12.4)\end{array}$ & $\begin{array}{l}\text { Fragaria nubicola }(36.3) \\
\text { Circaea alpina }(27.1) \\
\text { Triplostigea glandulifera }(17.5) \\
\text { Polygonum amplexicaule }(16.5) \\
\text { Viola biflora (13.7) }\end{array}$ \\
\hline $\begin{array}{c}\text { Kharsu } \\
\text { oak }\end{array}$ & $\begin{array}{l}\text { Fragaria nubicola }(25.3) \\
\text { Polygonum amplexicaule (18) } \\
\text { Selinum vegenatum. }(15) \\
\text { Viola biflora }(14.6) \\
\text { Primula sessilis }(10.9)\end{array}$ & $\begin{array}{l}\text { Fragaria nubicola }(18.3) \\
\text { Triplostigea glandulifera }(17.4) \\
\text { Polygonum amplexicaule }(13.5) \\
\text { Polygonum chinense }(6.15) \\
\text { Circaea alpina }(5.5)\end{array}$ \\
\hline Mixed & $\begin{array}{l}\text { Fragaria nubicola }(21.6) \\
\text { Polygonum amplexicaule (21.0) } \\
\text { Polygonum chinense }(20.7) \\
\text { Viola biflora }(19.15) \\
\text { Circaea alpina }(13.4) \\
\end{array}$ & $\begin{array}{l}\text { Circaea alpina (22.5) } \\
\text { Polygonum amplexicule }(17) \\
\text { Triplostigea glandulifera }(16.6) \\
\text { Fragaria nubicola }(12.5) \\
\text { Viola biflora }(9.1)\end{array}$ \\
\hline
\end{tabular}

(Tab. 4). Fragaria nubicola was most frequent and dominant component of the herb layer at timberline compared to subalpine forests. In the area of high grazing pressures and near to herders camp Polygonum polystachyum, Rumex nepalensis and Haeckelia uncinata were the dominant species, while Senecio alatus, Ainsliaea aptera and Polygonum amplexicaule were the dominant species in moist areas. A rare, parasitic herb, Balanophora involucrata was also recorded in birch and kharsu oak communities.

\section{Population structure}

Along the timberline ecotone regeneration status of all tree species was quite good as compared to subalpine forest, except the silver fir community. The conversion rate from seedling to sapling was negligible in disturbed area, while the highest number of seedlings and saplings were observed in birch community (Fig. 3A) followed by kharsu oak. In birch community higher girth class trees were less in number and attained maximum girth up to 101-120 cms. About $70 \%$ of the total population was represented by seedlings and saplings. The density presented to be the highest $(72 \%)$ in $21-40 \mathrm{~cm}$ girth class followed by $41-60$ $\mathrm{cm}$ class $(22 \%)$ in the community and Betula utilis contributed the most in all classes (seedling to tree). In silver fir community at timberline, regenerating individuals had $40 \%$ contribution and higher girth class trees were more in number (Fig. 3A). About $68 \%$ of the individuals in kharsu oak community were represented by the seedlings and saplings (Fig. 3A). About $23 \%$ of the tree individuals were represented in 41-60 cm girth class, while other classes were almost similar in occurrence. Mixed community had the highest percentage of regenerating individuals (84\%) and individuals were mostly distributed in $21-80 \mathrm{~cm}$ girth classes, whereas representation of the higher girth class trees was very poor (Fig. 3A).

With respect to timberline forest community, the regeneration was very poor in subalpine forest. The seedlings were found only in the areas of the tree fall/small forest gaps and along the edges due to rock or forest gap. Most of the individuals were distributed in higher girth classes. As compared to the timberline ecotone, the subalpine zone was represented by the trees of diverse girth classes in birch community (Fig. 3B). In silver fir community girth class distribution was similar to that of the timberline, where middle as well as higher girth class trees were represented by a greater number of individuals (Fig. 3B). Regeneration within the kharsu oak community was almost negligible as compared to the timberline ecotone and Rhododendron arboreum had the highest number of seedlings and samplings representing $72 \%$ of the community regeneration (Fig. 3B). The regenerating individuals (seedlings and saplings), in mixed community, represented $37 \%$ of the total density and the highest number of individuals in the community was distributed between $21-80 \mathrm{~cm}$ girth classes (Fig. 3B). 

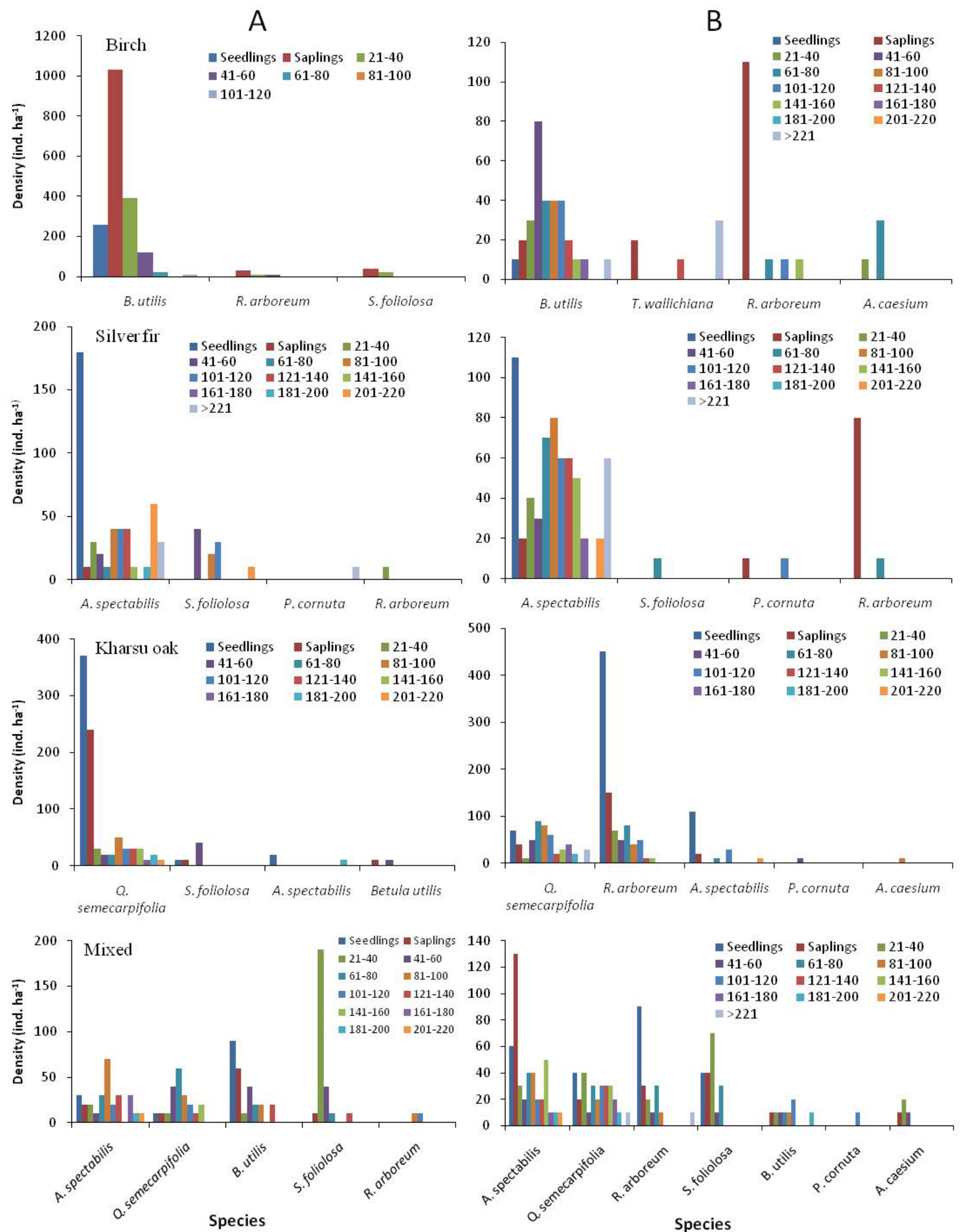

Fig. 3. Population structure of different communities along timberline ecotone (A) and subalpine forest (B) 
48

\section{Canopy architecture}

While crossing the subalpine forest, tree height, canopy cover and canopy width decrease, towards timberline zone, and physiognomy of community, at timberline ecotone, become sparse with open canopy. All these structural attributes were at the lowest in birch community. In the timberline zone tree height was the greatest in the silver fir community due to presence of old growth trees, whereas kharsu oak community had significant tree height in subalpine zone among all communities. More canopy cover and canopy depth in subalpine kharsu oak community was due to the presence of dense undercanopy, formed by $R$. arboreum, a major co-dominant species of the community. Due to less harsh climate and disturbance, ratio of canopy depth/tree height was higher along the subalpine zone $(0.77 \pm 0.03)$ than at timberline zone $(0.73 \pm 0.1)$. At more pronounced in the ecotones, which may vary with topography of the landscape and anthropogenic disturbance. Tewari and Singh (1985) reported that forests having $>60 \%$ crown cover as good, $30-60 \%$ as medium and $10-30 \%$ as poor forests, while crown cover in highly disturbed forests was $40 \%$. But, in case of timberline ecotone thinning of canopy is a natural process to optimize photosynthesis by receiving more sunlight during short growing period, but a broad ecotone and regenerating individuals is the primary condition at timberline (Tranquillini, 1979) in natural condition (absence of disturbance). The most consistent thing, which for centuries never stopped, in the high altitudes of Himalaya, was the anthropogenic disturbance in the form of lopping, logging, fuelwood consumption and grazing. From extensive forest clearing before independence and by revenue department just after

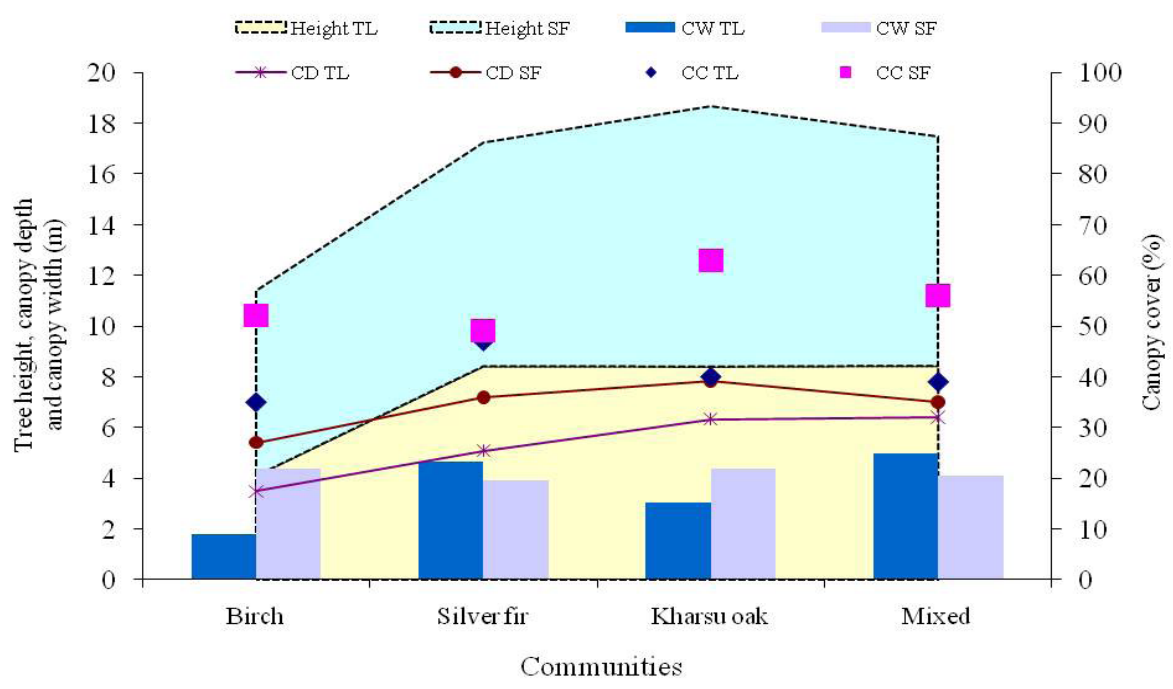

Fig. 4. Comparative representation of tree canopy depth, canopy height, canopy width and canopy cover of communities along the timberline and subalpine forests (TL: timberline, SF: subalpine forest; CD: canopy depth; CW: canopy width; CC: canopy cover)

timberline zone the highest ratio was observed in birch community (0.84), while silver fir community along the subalpine zone had the maximum ratio (0.81). Extreme climatic conditions (snow deposition, longer snowpack duration, aspect) and low disturbance in birch community, along timberline zone, leads to more canopy depth/ height ratio along the edges, whereas high disturbance level to less canopy depth/height ratio (0.6) in the silver fir community (Fig. 4).

\section{Discussion}

The aim of this study is to provide a detailed view of the locally varying timberline communities in KWS with reference to variations in the site conditions and disturbances. The structural and functional traits of any forest ecosystem are directly governed by the regional climate and topography. Spatial heterogeneity in structure and composition is independence to the current scenario high altitude forests were always under pressure in its different forms. From the extensive survey along the timberline in this region, it was obvious that timberlines always depressed and never attained their natural elevation of occurrence, except few localities, which were unapproachable. In many areas of KWS, remnant of the old trees in the higher altitude than the present timberlines were observed, which strongly support the present inference about the depression in the position of timberline. The areas approached by the seasonal shop holders and local herders were highly depressed and formed a timberline with sharp boundary. Ecotones resulting from the change in environmental gradients are hypothesized to be sensitive indicators of climate change (Rochefort et al., 1994), although the use of disturbanceregulated timberline ecotones to monitor climate change was questioned (Noble, 1993). The position of the timberline is affected by the complex interactions with past and 
current climates and various disturbances (Körner, 1998) and its position has been suggested as a sensitive indicator of climate change (Kullman, 1998), because an improved climate would be expected to rapidly influence growth of established individuals, but land use change (protection) in Western Himalaya would be prerequisite for it.

Uniform terrain along the climatic limit of survival led to the dominance of a single species in the entire landscape and to the formation of a more or less monoculture. Undulating topography (ridges or depressions) within the large slope sometimes provided opportunity to establish a small population of few other species within the habitat of major dominant species hence, maximum number of species had either random or contiguous distribution in the communities. Such conditions were found better for the forest health, which reflects increase in species richness. More tree species richness in mixed community at subalpine zone was due to the small scale topographic changes and aspects which supported species other than the dominant ones, while uniform condition in case of birch community resulted in the form of low species richness. Subalpine forest of the same community, at timberline, had ameliorated climatic conditions due to canopy trees, where microclimate was not much restricted to micro level and more species occupying the habitat. Birch community had higher shrub and herbaceous species richness, which might be due to low canopy cover of the community. Similar condition was also observed by Moral (1972), Whittaker and Niering (1975), Zobel et al. (1976) and Kumar and Ram (2005). Distribution of species along the timber- line was uneven and Shannon's diversity index was low due restricted distribution of co-dominant species in certain pockets. It was also reported that the regional patterns of species richness were the consequences of many interacting factors, such as plant productivity, competition and geographical area, historical or evolutionary development, regional species dynamics, environmental variables and human activity (Woodward, 1988; Zobel, 1997).

Forest degradation increases vulnerability of forest communities and lead to micro-climatic changes in turn strongly influences the composition of forest undercanopy (Chen et al., 1992; Kapos et al., 1995). A small change in the habitat affects negatively the species distribution. More shrub species similarity, among the communities in the subalpine zone as compared to timberline, indicated the altitudinal change of $100 \mathrm{~m}$ become habitat specific and restricted the distribution of species, which were more sensitive to the external disturbances at timberline zone. Highly disturbed timberline was least similar in term of species composition with other communities because well adapted species could survive under harsh conditions.

Tree density, in mixed community, was the greatest due to higher species richness than that of other communities, which were covering different layers of the canopy. Higher density in the birch community was due to the prevalence of lower girth class trees, which were negligible in other communities and old growth stands due to disturbance, led to the low tree density in other two communities. Higher total basal area of a community along the timberline indicates lack of low girth class trees, such as

Tab. 5. Comparative account for tree density and total basal area of similar communities across the Himalayan landscape

\begin{tabular}{|c|c|c|c|c|}
\hline Communities & Location & Tree density (Trees/ha) & $\operatorname{TBA}\left(\mathrm{m}^{2} / \mathrm{ha}\right)$ & Author \\
\hline \multirow{9}{*}{ Betula utilis } & Nyishang, Nepal ${ }^{*}$ & $1233-1284$ & $10.1-23.0$ & Shreshtha et al. (2007) \\
\hline & Pakistan & 688 & 34.0 & Ahmed et al. (2006) \\
\hline & Pindari & 560 & 26.0 & Kalakoti et al. (1986) \\
\hline & Askot WS & 470 & 21.4 & Dhar et al. (1997) \\
\hline & Sarju catchments & 450 & 31.3 & Rawal and Pangtey (1994) \\
\hline & Kumaun & 700 & 23.2 & Singh et al. (1994) \\
\hline & NDBR & $747-1206$ & $17.9-35.9$ & Rawal (1999) \\
\hline & Nanda Devi NP & $160-380$ & $4.4-23.6$ & Adhikari (2004) \\
\hline & KWS & $580-420$ & $6.4-28.5$ & Present study \\
\hline \multirow{5}{*}{ Abies spectabilis } & Melmjan, Nepal & $360-840$ & $43.1-118.2$ & Nakasuga (197)2 \\
\hline & Langtang NP, Nepal & 734 & 20.6 & Gaire et al. (2010) \\
\hline & NDBR (Lata) & 620 & 34.3 & Joshi and Samant (2004) \\
\hline & Nanda Devi NP & $160-760$ & $19.4-69.6$ & Adhikari (2004) \\
\hline & KWS & $420-520$ & $55.1-61.1$ & Present study \\
\hline Abies-Quercus & KWS & $780-780$ & $42.0-62.0$ & Present study \\
\hline \multirow{6}{*}{ Q. semecarpifolia } & Askot WS & 550 & 50.8 & Dhar et al. (1997) \\
\hline & Sarju catchments & 450 & 63.3 & Rawal and Pangtey (1994) \\
\hline & Kumaun & $250-2070$ & $5.0-114.0$ & Singh et al. (1994) \\
\hline & Pindari & 480 & 73.4 & Adhikari et al. (1995) \\
\hline & Binsar-Mahadev, Pauri & $310-520$ & $31.5-57.3$ & Baduni and Sharma (1996) \\
\hline & KWS & $340-810$ & $30.1-62.2$ & Present study \\
\hline
\end{tabular}

${ }^{*}$ Included $>10 \mathrm{~cm}$ girth classes 
50

in silver fir community, which is higher along timberline as compared to other studies in the Himalayan region. A comparative account of density and total basal area of the subalpine forests was given in Tab. 5 .

In the present study area disturbance had influenced shrub layer composition and distribution of species along the ecotone. The shrub density was found decreasing with increase in disturbance level, while herb density increased. In birch community shrub density presented the highest among all the communities and lowest in silver fir community. While herb density was lowest in birch community but presence of many rare species such as Lady's slipper orchid (Cypripedium spp., Rai et al., 2010), and Balanophora involucrata along the edge of forest indicated the importance of this transition for the rare species. Herb density was highest in silver fir community due to abundant growth of the species favoring the disturbance, and compact and damp soil condition. The species were unable to attain sufficient growth due to high grazing pressure, while found in large number. The dominance of one layer might affect diversity of another stratum (Whittaker, 1972) and vice-versa. The shrub density was higher along the subalpine forests of these communities, where disturbance was comparatively lower than that of timberline ecotone.

Throughout the Western Himalaya, very poor regeneration along the timberline ecotone and poor conversion rate from seedlings to saplings was observed. Canopy openness due to natural as well as anthropogenic disturbances always provided opportunity to seedlings establishment along the edges of forests. In the areas of low grazing pressure, good sapling numbers were observed such as in birch community, but negligible in the disturbed sites. In the highly disturbed areas seedlings were survived only in certain pockets, such as under the krummholz vegetation and unable to survive up to sapling stage. Unsuccessful regeneration along the disturbed timberlines of Western Himalaya might lead to the severe ecosystem instability in the events of predicted climate change, if species will shift upward in the altitudes in future. These species might have no space to migrate upwards due to disturbance or other species may replace these species. The high density of Betula utilis seedlings along the timberline of its own community indicated favorable climatic conditions in recent decades, which allowed growth and survival of seedlings beyond the canopy shelter.

The present study revealed that the area was one of the richest areas in terms of community heterogeneity, but it was under high anthropogenic pressure. Most of the areas lacking natural condition (broad transition zone with krummholz vegetation) and sharp timberlines were formed which terminated abruptly. The small scale heterogeneity in the structure and composition was due to topographic variation. High heterogeneous conditions reflect restricted distribution of the communities across the timberline, which may lead to more vulnerability in the present state of disturbances. Many species present only along the edges of forest might be facing severe threat in the form of population decline, which might lead to local extinction of species from that region. The narrow range species (altitudinal range) might be more under pressure under changing climatic conditions with high anthropogenic pressure. In the naturally protected area timberline species showing high regeneration towards the alpine area beyond the canopy shelter, this indicated some ameliorated conditions for growth and survival of seedlings in the recent decades. A good number of seedlings and saplings beyond $10-15 \mathrm{~m}$ from the edge of forest were observed in this area. If present climatic conditions would prevail in the Himalayan region; these timberlines (especially $B$. utilis which grow in tough terrains) would be showing shift in the altitude unless anthropogenic pressure not influences the establishment of seedlings up to maturity, which would strongly influence the biodiversity, species distribution and ecosystem balance in the Himalayan region. Long term monitoring is necessary to find out impacts of anthropogenic disturbances and climate change on timberline vegetation, which is of prime importance in biodiversity conservation.

\section{Acknowledgments}

The authors are thankful to Director and Dean, WII for encouragements and funding support and Uttarakhand Forest Department for permission and U.S. Rana for help during field work.

\section{References}

Adhikari BS (2004). Ecological attributes of vegetation in Nanda Devi National Park. Biodiversity monitoring expedition, Nanda Devi 2003. Wildlife Institute of India. Dehradun.

Adhikari BS, Rawat YS, Singh SP (1995). Structure and function of High altitude forests in Central Himalaya. I. Dry Matter dynamics. Ann Bot 75:237-248.

Adhikari BS, Rawat GS, Rai ID, Bharti RR, Bhattacharyya $S$ (2011). Ecological assessment of timberline ecotone in western Himalaya with special reference to climate change and anthropogenic pressures. IV Annual Report, Wildlife Institute of India, Dehradun, India.

Ahmed M, Husain T, Sheikh AH, Hussain SS, Siddiqui MF (2006). Phytosociology and structure of Himalayan forests from different climatic zones of Pakistan. Pak J Bot 38:361383.

Agrawala NK (1973). Working plan for the Kedarnath Forest Division 1972-73 to 1981-82. Working plan circle, Nainital, Uttar Pradesh.

Alftine KJ, Malanson G (2004). Directional positive feedback and pattern at an alpine treeline. J Veget Sci 15:3-12.

Baduni NP, Sharma CM (1996a). Effect of aspect on the structure of some natural stands of Cupressus torulosa in Himalayan moist temperate Forest. Proc Ind Nat Sci Acad B62:345-352. 
Cairns DM, Moen J (2004). Herbivory influences tree lines. J Ecol 92:1019-1024.

Camarero JJ, Gutiérrez E (2007). Response of Pinus uncinata recruitment to climate warming and changes in grazing pressure in an isolated population of the Iberian system (NE Spain). Arctic, Antarctic Alpine Res 39:210-217.

Chen J, Franklin JF, Spies TA (1992). Vegetation responses to edge environment in old growth Douglas fir forests. Ecol Applic 2:387-396.

Curtis JT, McIntosh RP (1950). The interrelations of certain analytical and synthetic phytosociological characters. Ecology 31:434-455.

Dhar U, Rawal RS, Samant SS (1997). Structural diversity and representativeness of forest vegetation in a protected area in Kumaun Himalaya, India: implication for conservation. Biodiv Conserv 6:1045-1062.

Gaire NP, Dhakal YR, Lekhak HC, Bhuju DR, Shah SK (2010). Vegetation Dynamics in Treeline Ecotone of Langtang National Park, Central Nepal, Nepal. J Sci Technol 11:107114.

Gansser A (1964). Geology of the Himalayas. Interscience Publication. John Wiley and Sons, London.

Grace J, Berninger F, Nagy L (2002). Impacts of climate change on the tree line. Ann Bot 90:537-544.

Gupta RK (1964). Forest types of the Garhwal Himalaya in relation to edaphic and geological formations. Ind For 4:147-160.

Holtmeier FK (2003). Mountain timberlines-Ecology, Patchiness and Dynamics. Kluwer Academic Publishers, The Netherlands.

Joshi HC, Samant SS (2004). Assessment of forest vegetation and conservation priorities of communities in part of Nanda Devi Biosphere Reserve, West Himalaya. Part I. Internat J Sust Develop World Ecol 11:326-336.

Kalakoti BS, Pangtey YPS, Saxena AK (1986). Quantitative analysis of High altitude vegetation of Kumaun Himalaya. J Ind Bot Soc 65:184-196.

Kapos V, Ganade G, Matsui E, Victoria RL (1995). $\mathrm{d}^{13} \mathrm{C}$ as an indicator of edge effects in tropical rain forest reserves. J Ecol 81:425-432.

Körner C (1998). A re-assessment of high altitude treeline positions and their explanation. Oecologia 115:445-459.

Körner C, Paulsen J (2004). A world-wide study of high altitude treeline temperatures. J Biogeography 31:713-732.

Kullman L (1998). Tree-limits and montane forests in the Swedish Scandes: Sensitive biomonitors of climate change and variability. Ambio 27:312-321.

Kumar A, Ram J (2005). Anthropogenic disturbances and plant biodiversity in forests of Uttaranchal, central Himalaya. Biodiv Conserv 14:309-331.

MacDonald GM, Szeicz JM, Claricoates J, Dale KA (1998). Response of the Central Canadian Treeline to recent climatic changes. Ann Assoc Am Geographers 88:183-208.
Magurran AE (1988).Ecological Diversity and its Measurements. University Press, Cambridge.

Moral RD (1972). Diversity patterns in forest vegetation of the Wenatchee Mountains, Washington. Bull Forrey Bot Club 99:57-64.

Nakasuga T (1972). An Investigation on Forests in Nepal. Res Bull College Experim For 24:155-174.

Noble IR (1993). A model of the responses of ecotones to climate change. Ecol Applic 3:396-403.

Parmesan C (2006). Ecological and evolutionary responses to recent climate change. Ann Rev Ecol Evol System 37:637669.

Phillips EA (1959). Methods of Vegetation Study. Henry Holt and Co. Inc., New York.

Pielou EC (1966). The measurement of diversity in different types of biological collections. J Theoret Biol 13:131-144.

Rai ID, Adhikari BS, Rawat GS (2010). A unique patch of timberline ecotone with three species of Lady's slipper orchids in Garhwal Himalaya, India. J Threatened Taxa 2:766-769.

Rawal RS (1999). Studies on species and community responses to habitat alterations in timberline zone of proposed Uttarakhand Biosphere Reserve: Management implications. Final Technical Report Submitted to Ministry of Environment and Forest, New Delhi.

Rawal RS, Pangtey YPS (1994). High altitude forest vegetation with special reference to timberline in Kumaun central Himalaya, 353-399 p. In: Pangtey YPS, Rawal RS (Eds.). High Altitudes of the Himalaya. Gyanodaya Prakashan, Nainital, India.

Rochefort RM, Little RL, Woodward A, Peterson DL (1994). Changes in sub-alpine tree distribution in western North America: a review of climatic and other causal factors. The Holocene 4:89-100.

Shannon CE, Weaver W (1963). The Mathematical Theory of Communication. University of Illinois Press, Urbana, Illinois.

Shugart HH, Saatchi S, Hall FG (2010). Importance of structure and its measurement in quantifying function of forest ecosystems. J Geophysical Res 115 (G00E)13-16.

Shugart HH, French NHF, Kaslschke ES, Stawski JJ, Dull CW, Shuchman RA, Mwangi J (2001). Detection of vegetation change using reconnaissance imagery. Global Change Biol 7:247-252.

Singh SP, Adhikari BS, Zobel DB (1994). Biomass, Productivity, leaf longevity and forest structure in the central Himalaya. Ecol Monographs 64:401-421.

Shreshtha BB, Ghimire B, Lekhak HD, Jha PK (2007). Regeneration of Treeline Birch (Betula utilis D. Don) Forest in a Trans-Himalayan Dry Valley in Central Nepal. Mount Res Develop 27:259-267.

Sorenson T (1948). A method of establishing groups of equal amplitude in plant sociology based on similarity of 
52

species content. Detkong Danske Vidensk Selk biol Skr (Copenhagen) 5:1-34.

Stapanian MA, Cassel DL, Cline SP (1997). Regional patterns of local diversity of trees: associations with anthropogenic disturbance. For Ecol Manage 93:33-44.

Timilsina N, Ross MS, Heinen JT (2007). A community analysis of sal (Shorea robusta) forests in the western Terai of Nepal. For Ecol Manage 241:223-234.

Tewari JC, Singh SP (1985). Analysis of woody vegetation in a mixed oak forest of Kumaon Himalaya. Proc Ind Nat Sci Acad 51:332-347.

Tranquillini W (1979). Physiological ecology of alpine timberline. Springer-Verlag Berlin Heidelberg, New York.

Wardle P (1974). Alpine timberlines, 371-402 p. In: Ives JD, Barry R (Eds.). Arctic and Alpine Environments. Methuen Publishing, London.

Weiher E, Howe A (2003). Scale-dependence of environmental effects on species richness in oak savannas. J Veget Sci 14:917-920.

Weiser C, Tuasz M (2007). Synopsis, 219-223 p. In: Wieser G, Tuasz M (Eds.). Trees at their upper limit: Tree life limitations at the alpine tree line. Springer, Dordrecht.
Whittaker RH (1972). Evolution and measurement of species diversity. Taxon 21:213-251.

Whittaker RH (1975). Communities and ecosystem, $2^{\text {nd }} e d$. McMillan Publishing Co. Inc. New York.

Whittaker RH, Niering WA (1975). Vegetation of the Santa Catalina Mountains, Arizona. V. Biomass production and diversity along the elevation gradient. Ecology 56:771-790.

Whittaker RJ, Willis KJ, Field R (2001). Scale and species richness: towards a general, hierarchical theory of species diversity. J Biogeography 28:453-470.

Woodward FI (1988). Temperature and the distribution of plant species and vegetation, 59-75 p. In: Long SP, Woodward FI (Eds.). Plants and Temperature. Society of Experimental Biology by The Company of Biologists Limited. Cambridge.

Zobel M (1997). The relative role of species pools in determining plants species richness: an alternative explanation of species coexistence. Trends Ecol Evolut 12:266-269.

Zobel DB, McKee A, Hawk GM, Dyrness CT (1976). Relationship of environment to composition, structure and diversity of forest communities of the central, western cascades of Oregon. Ecol Monograph 46:135-156. 